\title{
A Neglected case admitted with paraplegia: An intradural extramedullary epidermoid cyst
}

\author{
ihmal edilmiş paraplejik bir olgu: Intradural ekstramedüller epidermoid kist
}

\author{
Nihal Özaras ${ }^{1}$, Mustafa Akif Sarıyıldız², Saliha Eroğlu Demir¹, Feyza Karagöz Güzey³, Abdurrahman Aycan \\ Meltem Esenyel ${ }^{4}$ \\ ${ }^{1}$ Department of Physical Medicine and Rehabilitation, Bezmialem Vakıf University Medical Faculty, İstanbul, Turkey \\ ${ }^{2}$ Department of Physical Medicine and Rehabilitation, Dicle University Medical Faculty, Diyarbakır, Turkey \\ ${ }^{3}$ Neurosurgery Clinic, Ministry of Health Bagcilar Research and Training Hospital, Istanbul, Turkey \\ ${ }^{4}$ Physical Medicine and Rehabilitation Clinic, Ministry of Health Göztepe Research and Training Hospital, Istanbul, Turkey
}

\begin{abstract}
Spinal epidermoid tumors are rare tumors, constituting about $1.5-2 \%$ of the spinal tumors. Cervical and thoracic spinal cord epidermoid tumors are exceedingly rare. We reported a case of a 28-year-old patient with an intradural extramedullary epidermoid cyst at the thoracic region presented with urinary incontinence and paraparesis to our outpatient clinic. First symptoms of patient started 16 years ago and diagnosed as peroneal muscular atrophy and he couldn't be investigated sufficiently. Because of the delayed diagnosis and treatment, paraparesis and urinary incontinence were persistent in spite of successful surgery and proper physical therapy. Spinal epidermoid tumors have a good prognosis, as they are histologically benign. When diagnosed early, complete surgical resection offers the patient good neurologic outcome. It is important to investigate extensively patients with neurological deficits and to make diagnosis as soon as possible. $J$ Clin Exp Invest 2012; 3(2): 270-272
\end{abstract}

Key words: Epidermal cyst, spinal cord compression, spinal cord neoplasms, paraplegia, early diagnosis

\section{INTRODUCTION}

Spinal epidermoid tumors are rare, less than $1 \%$ of all spinal tumors. ${ }^{1-3}$ Most of them are intradural and extramedullary. ${ }^{3,4}$ These tumors are generally found in the lumbosacral region..$^{1,5}$ The symptoms and signs of these tumors are not different from other spinal space occupying lesions in the spinal column and dependent on the level of the lesion. ${ }^{1,3}$ They are slow-growing lesions. It is highly possible to resolve symptoms completely following surgical removal if the tumor detected early. ${ }^{1,2}$ We reported a case of a thoracic level epidermoid tumor causing progres-

\section{ÖZET}

Spinal epidermoid tümörler, spinal tümörlerin \%1.5-2'sini oluşturan nadir tümörlerdir. Servikal ve torasik spinal kord epidermoid tümörleri oldukça nadirdir. Bu yazıda polikliniğimize üriner inkontinans ve paraparezi ile başvuran torasik bölgede intradural ekstramedüller epidermoid kist tespit edilen 28 yaşında bir olgu sunuldu. Hastanın ilk şikayetleri 16 yı önce başlamış. Bu dönemde hastaya peroneal muskuler atrofi teşhisi konulmuş ve ayrıntılı tetkik edilememiş. Geç tanı ve tedavi nedeniyle başarılı cerrahi ve kapsamlı fizik tedaviye rağmen mevcut paraparezi ve üriner inkontinans düzelmedi. Spinal epidermoid tümörlerin prognozu histolojik olarak benign oldukları için iyidir. Erken teşhis edilirse tam cerrahi rezeksiyon hastaya iyi nörolojik sonuç sağlar. Nörolojik defisiti mevcut olan hastaların kapsamlı araştııııması ve en erken sürede teşhis konulması hayati önem taşımaktadır.

Anahtar kelimeler: Epidermal kist, omirilik sıkışması, omirilik neoplazileri, parapleji, erken tanı

sive paraparesis for 16 years in a 28 -year-old male. Because the delayed diagnosis, his neurological deficits did not improve at postoperative follow-up. The cruciality of early diagnosis of spinal epidermoid tumors is emphasized.

\section{CASE}

A 28 year-old man presented to our clinic with complaints of inability to walk, weakness of both lower limbs and urinary incontinence. He was ambulant with wheelchair. His history was notable for the beginning of the symptoms 16 years ago. He

Correspondence: Dr. Saliha Eroğlu Demir, Bezmialem Vakıf University Medical Faculty, Department of Physical Medicine and Rehabilitation, İstanbul, Turkey Email: saliha45@yahoo.com Received: 10.02.2012, Accepted: 29.04.2012 
had fallen down from the second floor at the age of 12. His symptoms had started after that traumatic event, and showed progression over the time. The weakness had initially involved the right lower limb and then the left.. The patient had never applied to any doctor until the age of twenty. At that time, the diagnosis had been thought as 'peroneal muscular atrophy' and proposed further investigations. These investigations hadn't been performed due to lack of patient's health insurance. He had no prior history of lumbar punctures and no particular family history of peripheral nerve paralysis or other neurological disorders.

On physical examination, no patch or dermal orifice on his back was found. Pes equinovarus deformity was present in his feet. Active and passive range of motion in the bilateral joint of knee and hip were full. On manual muscle test, muscle weakness was found in hips' extensors (3/5 on the right and $4 / 5$ on the left), left hip's flexors (4/5), right knee's extensors (4/5). There was no active motion on the ankles or toes. There was sensory loss in the left S1 dermatome and bilateral S2-5 dermatomes. Patellar reflex was bilateral abolic. Because of the deformities, achille's reflex could not be examined. There was no pathological reflex. Tonus of lower extremities was flaccid.

Lumbar spinal Magnetic Resonance Imaging study (MRI) showed severe atrophy in medulla spinalis and conus medullaris including lower thorax and lumbar region (Figure 1). Thorax MRI demonstrated an intradural extramedullary mass formation with lobule contour characterized by cystic changes causing marked posterior displacement and compression of medulla spinalis at the thorax spinal canal beginning from T12 level (Figure 2). No dermal sinus tract or any other developmental abnormality was noted on MRI. In the light of these findings, benign cystic neoplasia was thought and the distinctive diagnosis included ependimoma with cystic degeneration.

The patient underwent T11-T12 and L1 laminotomy and the mass between T10-L2 was totally excised. The postoperative course was uneventful. The tumour was sent for histopathological evaluation which confirmed the diagnosis of an epidermoid. There wasn't significant improvement in physical and neurological examination at the end of postoperative two months.

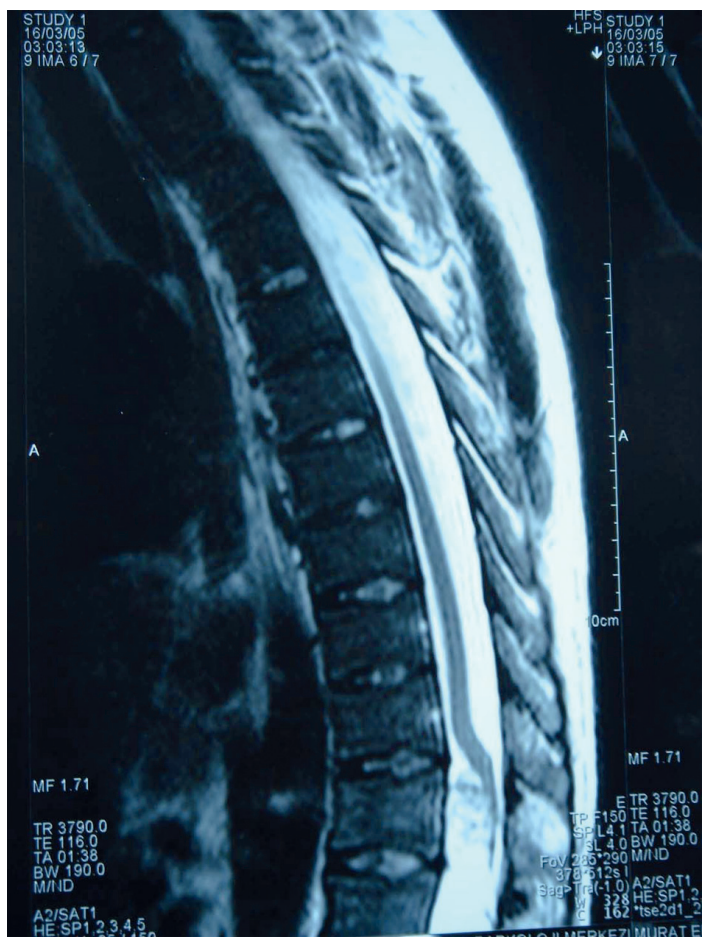

Figure 1. Sagittal Magnetic Resonance image of the lumbar spine showed severe atrophy in medulla spinalis and conus medullaris including lower thorax and lumbar region.

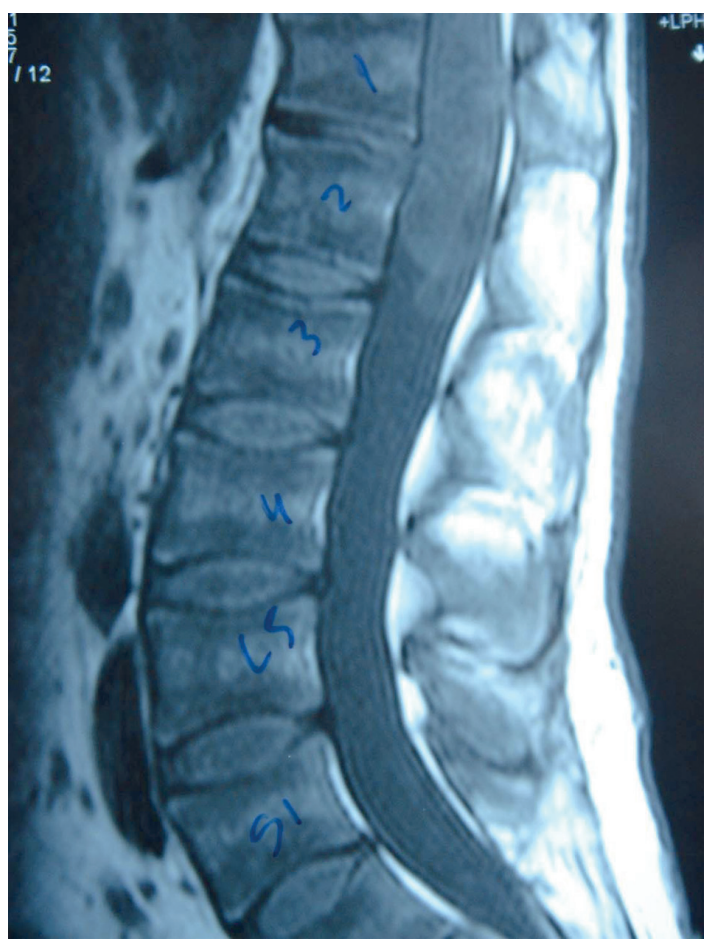

Figure 2. Sagittal Magnetic Resonance image of the thorax spine demonstrated an intradural extramedullary mass formation with lobule contour characterized by cystic changes. 


\section{DISCUSSION}

Epidermoid cysts of the spinal cord are rare tumors in the adult population. The incidence of thoracic epidermoids is approximately $0.8 \%$ of all spinal epidermoids. ${ }^{1}$ Intraspinal epidermoid cysts may be congenital or acquired. Congenital spinal epidermoids are related to inclusion of ectoderm at the time of closure of the neural tube between the $3^{\text {rd }}$ and $4^{\text {th }}$ weeks of fetal life. ${ }^{3,5}$ Acquired epidermoid cysts are thought to result from iatrogenic penetration of skin fragments, especially after single or multiple lumbar spinal punctures or after meningomyelocele repairs. ${ }^{3,4}$ It is questionable whether an acquired origin can be excluded in the present case. He had no patch or dermal orifice on his back. He did not have history of lumbar puncture or tuberculous meningitis either. After the traumatic event at the age of 12 , he or his family had not realized any obvious injury or open wound at his back region. However; his symptoms had started immediately after this trauma. Although it cannot be proven whether this cyst developed as the result of the trauma, it was thought that the trauma was clearly related to the onset of symptoms.

Aside from patients with congenital anomalies, plain radiographs were uniformly unremarkable in patients with intradural spinal cysts. ${ }^{6}$ Once there is any suspicion of a spinal cord lesion, the preferable diagnostic modality is MRI of the spinal cord. ${ }^{7}$ These cysts usually give low signal intensity on T1weighted images and high signal intensity on T2weighted images. ${ }^{5}$ Radiographic characteristics of epidermoids typically show a displacement of nerve roots and the spinal cord in the subdural space. ${ }^{1}$

Epidermoid tumors are well tolerated by patients for long periods of time, ranging from 2 to 10 years. ${ }^{8}$ Symptoms may often arise for the first time in early or middle adult life and are directly related to tumor size and site. ${ }^{1}$ Signs and symptoms at presentation are usually neurological, such as progressive paraparesis, sensory loss, urological manifestations and back/leg pain. ${ }^{4}$ The most common clinical presentation is the insidious onset of a slowly progressive myelopathy. ${ }^{6}$ In the present case, the interval to diagnosis was 16 years. The initial nonspecific signs and symptoms, slowly progressive neurological deficits and poor family condition had resulted delayed diagnosis.

The prognosis for epidermoid tumors of the spine is good, since they have histologically benign nature. ${ }^{1,8}$ Because long-standing neurological deficits may become irreversible, patients with neurological findings should undergo surgery when the diagnosis is made. ${ }^{6}$ Complete surgical resection can result in a good neurologic outcome. ${ }^{1}$ Our patient's family had no social insurance. They had not brought their child to the doctor for comprehensive investigation until 18 year-old. At the age of 18 , the diagnosis had been made as peroneal muscular atrophy. We thought that the erroneous diagnosis had been made because of the deformities in his feet with neurological findings and unremarkable plain radiographs. Although further investigations had been recommended at that period, the family's condition could not allow them to do. After he had been social insurance, he had never been investigated for his gait impairment until he was admitted to our clinic. Because of the delayed diagnosis and treatment, paraparesis and urinary incontinence were persistent in spite of successful surgery and physical therapy.

It is important to investigate extensively patients with neurological deficits and to make the diagnosis as soon as possible. In the early stage of a neurological deficit, a comprehensive medical history and an adequate neurological investigation followed by MRI of the spinal cord are important issues to decrease the time to diagnosis. If the diagnosis could not be made earlier, this will provide poor prognosis like the present patient.

\section{REFERENCES}

1. Scarrow AM, Levy El, Gerszten PC, Kulich SM, Chu CT, Welch WC. Epidermoid cyst of the thoracic spine: case history. Clin Neurol Neurosurg 2001;103(4):2202.

2. Gonzalvo A, Hall N, McMahon JH, Fabinyi GC. Intramedullary spinal epidermoid cyst of the upper thoracic region. J Clin Neurosci 2009;16(1):142-4.

3. Cataltepe O, Berker M, Akalan N. A giant intramedullary spinal epidermoid cyst of the cervicothoracic region. Pediatr Neurosurg 2004;40(3):120-3.

4. Ferrara $P$, Costa $S$, Rigante $D$, et al. Intramedullary epidermoid cyst presenting with abnormal urological manifestations. Spinal Cord 2003;41(11):645-8.

5. Teksam M, Casey SO, Michel E, Benson M, Truwit CL. Intraspinal epidermoid cyst: diffusion-weighted MRI. Neuroradiology 2001;43(7):572-4.

6. Osenbach RK, Godersky JC, Traynelis VC, Schelper RD. Intradural extramedullary cysts of the spinal canal: clinical presentation, radiographic diagnosis, and surgical management. Neurosurgery 1992;30(1):3542.

7. Jellema K, Overbeeke JJ, Teepen HL, Visser LH. Time to diagnosis of intraspinal tumors. Eur $\mathrm{J}$ Neurol 2005;12(8):621-4.

8. Reina M, Lopez-Garcia A, Dittmann M, de Andres J, Blazquez M. latrogenic spinal epidermoid tumors. A late complication of spinal puncture. Rev Esp Anestesiol Reanim 1996;43(4):142-6. 